๑ Entomologica Fennica. 29 December 2003

\title{
Flagellar sensilla in male and female European beewolves, Philanthus triangulum F. (Hymenoptera: Sphecidae)
}

\author{
Gudrun Herzner*, Thomas Schmitt, K. Eduard Linsenmair \& Erhard Strohm
}

Herzner, G., Schmitt, T., Linsenmair, K. E. \& Strohm, E. 2003: Flagellar sensilla in male and female European beewolves, Philanthus triangulum F. (Hymenoptera: Sphecidae). — Entomol. Fennica 14: 237-247.

\begin{abstract}
We investigated the morphology of the antennal sensilla of a sphecid wasp, the European beewolf Philanthus triangulum, to provide an inventory for the species and to compare the sensillar equipment between the sexes. The density of sensilla increased from the base to the tip of the antennae. We distinguished nine different types of sensilla. One type has not yet been described in Hymenoptera. The large sensilla basiconica occurred only on the antennae of female beewolves. We discuss the functional significance of the difference between the sexes and compare our results with data from other sphecids and the honeybee Apis mellifera.
\end{abstract}

Gudrun Herzner, Thomas Schmitt, K. Eduard Linsenmair \& Erhard Strohm, Theodor-Boveri-Institut für Biowissenschaften, Zoologie III, Biozentrum, Am Hubland,D-97074 Würzburg,Germany; (*E-mail herzner@biozentrum.uniwuerzburg.de)

Received 11 April 2003, accepted 28 June 2003

\section{Introduction}

Insects heavily rely on the perception of chemical stimuli for foraging and intraspecific as well as interspecific communication (e.g. Cossé et al. 1995, Attygalle et al. 1996, Nishida et al. 1996, Yarden et al. 1996, Paulmier et al. 1999, Drijfhout $\&$ Groot 2001). The most important receptor organs in this case are antennal sensilla. Accordingly, insect antennae possess a considerable diversity and high density of sensilla with an olfactory or gustatory function (Inouchi et al. 1987, Isidoro et al. 1996, Kim \& Leal 2000). The incidence, density, and distribution of different types of sensilla differ among species and, to a variable extent, between sexes within a species (Esslen \& Kaissling 1976, Ågren 1978, Martini 1986a,
Jourdan et al. 1995, van Baaren et al. 1999). These differences in sensillar equipment are probably related to differences in ecology, mating system and other behavioral aspects of the species or the sexes (Wcislo 1995, Merivee et al. 1999).

In order to maximize their reproductive success, females should be selected to find food resources or oviposition sites (e.g. certain plant species) most effectively. By contrast, the primary interest of males is to locate females (Phelan 1992, 1997). Thus, the most relevant odors differ between males and females. As a consequence, the abundance and/or distribution of different types of sensilla on the antennae of males and females might differ. This difference is probably most pronounced in species where either males or females are highly specialized. In this study, we 
investigated the sensillar typology and distribution on the antennae of males and females of a sphecid wasp, the European beewolf Philanthus triangulum, using scanning electron microscopy (SEM) and light microscopy (LM). Since the sexes differ considerably in this species with regard to the chemical stimuli that are most important for reproduction, we expected differences in their sensory system.

For males of the European beewolf olfaction is primarily important in two (perhaps three) different contexts. First, they scent-mark territories to attract receptive females (Evans \& O'Neill 1988, Strohm \& Lechner 2000). Males regularly visit neighboring territories and hover downwind, possibly assessing the intensity of their neighboring male's odor (E. Strohm, pers. obs.). Males might use this information to regulate the frequency of their marking runs to match the intensity of their odor to neighboring territories. Thus, males probably perceive the sexual pheromone. Second, males feed on flowers, in the study region mostly on thistle (Cirsium arvense) and goldenrod (Solidago canadensis) (see also Olberg 1953). Thus, males have to perceive flower odors. During the night males stay in small burrows in sandy soil which they probably find by visual stimuli, but olfaction might also be involved (E. Strohm, unpublished observations). Probably none of the contexts mentioned above require extreme sensitivity on behalf of the males (as would be the case if males are attracted by female pheromones as in many moths, see e.g. Schenk [1903] and Hansson [1995]). There is no evidence for any aphrodisiacs emitted by females of the European beewolf.

Females rely on olfaction in mainly four different contexts. First, and probably most important, is the foraging for larval provisions. Female European beewolves are highly specialized in that they exclusively hunt workers of honeybees, Apis mellifera. Beewolf females search for honeybees on flowers. They approach a potential prey and identify it while hovering downwind (Tinbergen 1935). Then the beewolf female pounces on the bee and paralyzes it by stinging. The paralyzed prey is then carried in flight to a nest that has been excavated in bare sandy soil. One to six paralyzed bees are provisioned in a brood cell and an egg is laid on one of the bees. The larva feeds on the bees, spins into a cocoon and hibernates and emerges next summer. The location and identification of honeybees is the most important component of female reproduction. Thus, females should have a suitable sensory equipment to detect their prey. Second, females have to locate a male territory for mating. Females most probably mate only once a few days after emergence (Evans \& O'Neill 1988). Third, in particular when returning with prey, females have to locate their nests reliably and quickly in order to minimize the probability of parasitism (Evans \& O'Neill 1988, Strohm et al. 2001). The location of the nest is mainly accomplished by visual stimuli (Tinbergen 1932, Tinbergen \& Kruyt 1938). However, olfaction is probably involved in the identification of the nest (E. Strohm, pers. obs.). Finally, females also feed on floral nectar. However, they rely much less on nectar than males since for their own energy supply they primarily feed on the nectar content of the paralyzed honeybees' crops (Rathmayer 1962).

This study has two aims. Firstly, we give an inventory of the sensilla on the antennae of male and female European beewolves. Secondly, we ask whether the differences between male and female beewolves might have favored differences in the equipment with antennal sensilla. The higher complexity and importance of chemical stimuli that are relevant for females, lead to the expectation of more types of sensilla and possibly a higher density on female antennae. Sensilla types that are found on female but not on male antennae probably play a role in the location and/or identification of the honeybee prey.

\section{Material and methods}

\subsection{Specimen}

Beewolf males and females were obtained from a laboratory population, reared at the Biocenter of the University of Würzburg, Germany, or taken from a field population nesting close to the Biocenter. In the laboratory, beewolves were kept in an environmental chamber at $26^{\circ} \mathrm{C} / 22^{\circ} \mathrm{C}$ day/night with a 14 h/10 h light/dark cycle. Males could establish territories and females were provided with honeybees ad libitum. Both sexes were fed with honey ad libitum. 


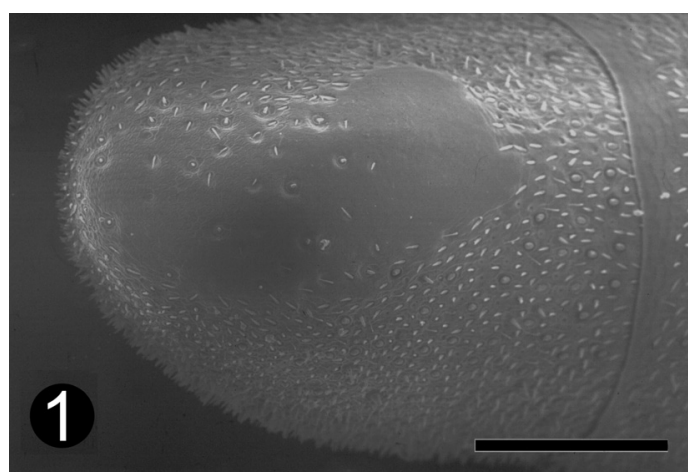

Fig. 1. Female, 10th annulus, ventral side. Kidneyshaped area almost free of sensilla and setae. The surrounding area bears a high density of different sensillar types. Scale bar $100 \mu \mathrm{m}$.

\subsection{Morphology}

For scanning electron microscopy (SEM) of the outer cuticular structures entire heads with antennae attached (for purposes of orientation) and excised antennae were used. Excised heads and antennae of freshly freeze-killed females were immediately fixed in alcoholic Bouin (Romeis 1989) for $24 \mathrm{~h}$, and then washed in $80 \%$ ethanol. Male heads and antennae were taken from chilled individuals, fixed in $6.25 \%$ glutar aldehyde and washed in phosphate buffer ( $\mathrm{pH} 7.4$ ). The antennae of both sexes were then dehydrated in a graded acetone series, critical point dried in $\mathrm{CO}_{2}(\mathrm{Bal}-\mathrm{Tec} \mathrm{CPD} 030$, Balzers, Liechtenstein) and glued (with conductive glue) onto the SEM supports. Finally the specimens were gold/ palladium-coated (Balzers Union MED010 sputter-coating unit, Balzers, Liechtenstein) and viewed in a Zeiss DSM962 scanning electron microscope at an acceleration voltage of $10-15 \mathrm{kV}$. Micrographs were taken with a Contax camera fitted to the SEM. Beewolves hold their antennae slightly upwards (about $30^{\circ}$ ), slightly outwards (about $15^{\circ}$ ), and entirely straight during flight. Thus, for positional information we consider the ventral side of the antenna the side facing downwards and the dorsal side the side facing upwards. The measurements are based on antennal sensilla from three females and three males.

The anatomy of the cuticular structures was investigated using standard histological techniques and light microscopy (LM). Antennae were fixed in $0.1 \mathrm{M}$ Cacodylate buffer containing $2.5 \%$ glutar aldehyde, $2 \%$ paraform aldehyde, $6 \%$ saccharose, and 2\% DMSO, embedded in Epon and cut to 1 or $2 \mu \mathrm{m}$ thick slices with an ultramicrotom (Reichert-Jung Ultracut) using a diamond knife. These semithin sections were mounted on glass slides, stained with methylene blue or AZAN (Romeis 1989) and observed with a light microscope (Leitz Laborlux S). Photographs were taken with a Nikon Coolpix 990 digital camera attached to the microscope.

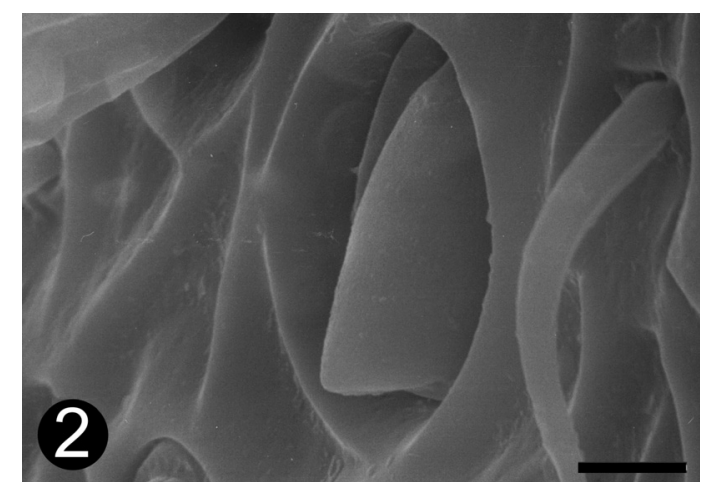

Fig. 2. Male, 2nd annulus, dorsal side. Sensillum placodeum. Scale bar $2 \mu \mathrm{m}$.

For the inventory of the sensilla we primarily follow the sensillar classification of Schenk (1903), Esslen \& Kaissling (1976), and Ågren (1977), based on morphological characters. This classification is however preliminary and should be replaced by that proposed by Altner (1977), when the internal structures of the sensilla and structurefunction relationships have been established.

\section{Results}

\subsection{General morphology of the antennae}

The antennae of $P$. triangulum are filiform. They are made up of a long scape at the proximal end, followed by a rounded pedicel, to which the flagellum is attached. Females have 10 flagellar annuli, males 11 . Annuli are counted from proximal to distal. The first annulus is considerably longer than all the other annuli. Compared to honeybees, the flagellum is rather thick. The cuticle between the sensilla or setae is coarser on the ventral than on the dorsal side. On the ventral side of the last annulus there is a conspicuous kidneyshaped, smooth area that bears very few sensilla or setae (Fig. 1).

\subsection{Sensilla and setae}

We were able to classify nine different types of sensilla, that are described in the following.

The sensilla placodea (so-called pore plates, Fig. 2) are oval shaped, about 7-8 $\mu \mathrm{m}$ long and 


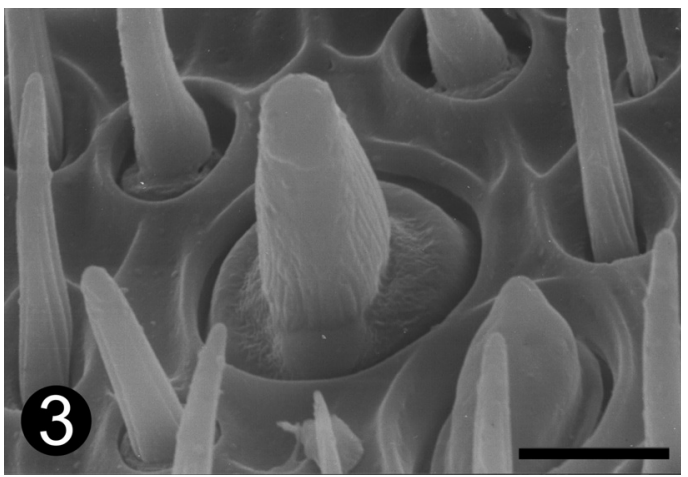

Fig. 3. Female, 10th annulus, dorsal side. Large sensillum basiconicum (note wide socket). Scale bar $5 \mu \mathrm{m}$.

3-4 $\mu \mathrm{m}$ wide with their longitudinal axis parallel to the longitudinal axis of the antenna. The distal end of the plate rises higher above the cuticle than the proximal end. The cuticular apparatus is encircled by a fissure and connected to the surrounding cuticle by a joint-like membrane. The plate of the sensillum bears many pores, which are arranged radially over the whole surface. The pore plates are the most numerous type of sensilla on the antennae of both males and females. They are found all around the annuli, although more rarely on the ventral side. In females they occur on annuli 1 to 10 dorsally, and 2 to 10 ventrally. Males have s. placodea on the annuli 2 to 11 on both sides of their antennae. The abundance of this sensillum is lowest on the first annulus and increases towards the tip of the antenna.

The large sensillum basiconicum (Fig. 3) has a longitudinally sculptured shaft that is ca. $10 \times 5$ $\mu \mathrm{m}$ in size. The shaft ends in a perforated dome constituting the blunt tip of the peg and has an apparently flexible socket that is about as wide as the length of the sensillum. The s. basiconica are restricted to females, where they can be found only dorsally or laterally on the inner side of annuli 310 . They increase in number from the proximal to the distal end of the antenna.

Pit organs (Fig. 4a) belong to the so-called "peg in pit" sensilla and are characterized by a round cuticular opening to the outside, in which no peg is visible. SEM investigations revealed that the two types cannot be easily distinguished by characters at the surface of the antenna. Although the cuticular openings of the s. ampullacea seem
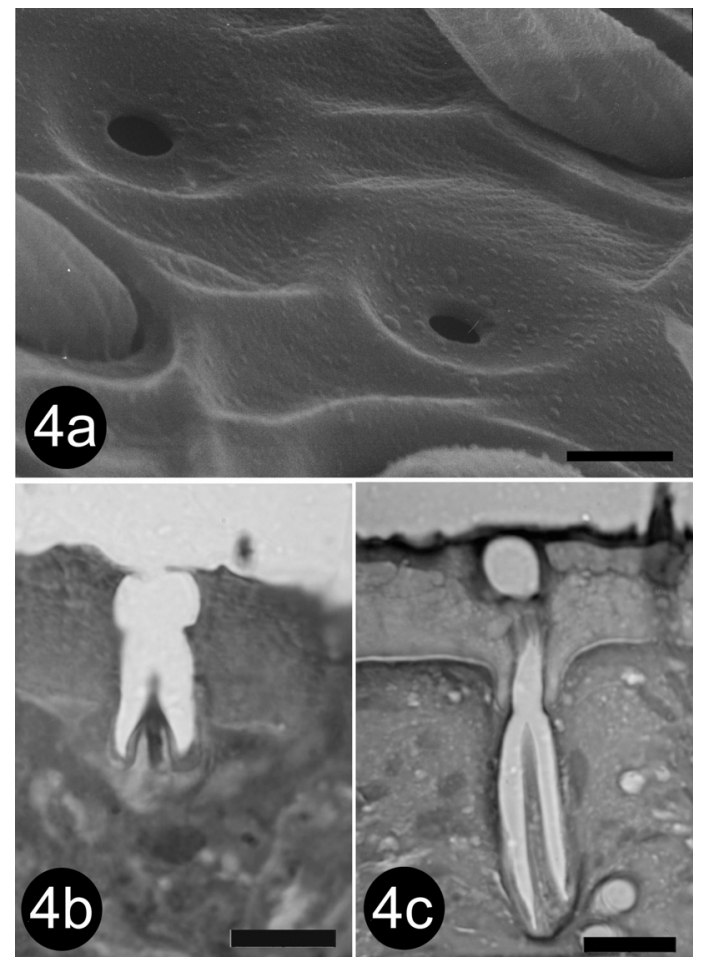

Fig. 4. Pit organs. - a. Female, 10th annulus, ventral side. Scale bar $2 \mu \mathrm{m}$. - b. sensillum coeloconicum (note the short peg, encircled by folds). Scale bar 10 $\mu \mathrm{m}$. - c. sensillum ampullaceum (note the long, slender peg). Scale bar $10 \mu \mathrm{m}$.

to be slightly smaller than the ones of the s. coeloconica, a clear differentiation of these two sensillar types was not possible. Therefore, we grouped them together as "pit organs" for the investigation of their distribution. Pit organs are found on the ventral side of the antennae in both sexes. Very few were found laterally on the outside of the flagellum. Male antennae bear pit organs on the annuli 3 to 11 , female antennae on the annuli 2-10. The density of pit organs increases towards the tip of the antenna.

In the semi-thin sections, we identified both s. coeloconica (Fig. 4b) and s. ampullacea (Fig. 4c) unambiguously. The s. ampullacea have a peg situated at the bottom of a 40-50 $\mu \mathrm{m}$ long and 6.7$8.5 \mu \mathrm{m}$ wide ampulla or tube. The length of the longitudinally furrowed peg is $20-25 \mu \mathrm{m}$, the diameter $2-2.7 \mu \mathrm{m}$. In contrast, the s. coeloconica are characterized by an only $17-20 \mu \mathrm{m}$ deep and 8.4-10.2 $\mu \mathrm{m}$ wide cavity, two thirds of which are 


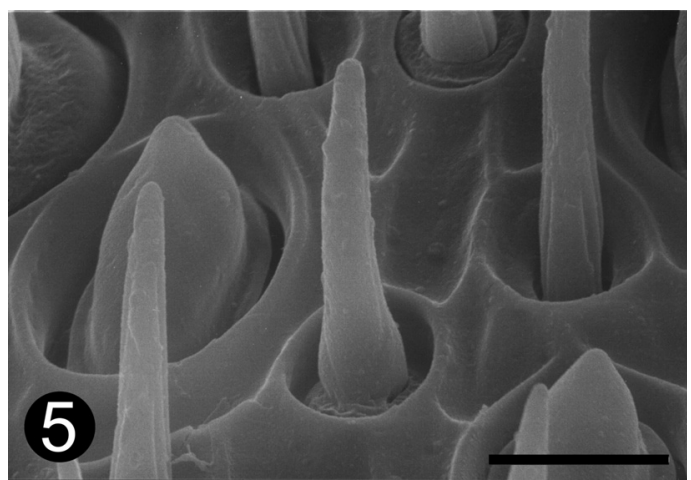

Fig. 5. Female, 10th annulus, dorsal side. Sensillum trichodeum A. Scale bar $5 \mu \mathrm{m}$.

embedded within the thick cuticle. They possess a much shorter central peg $(8-10.7 \mu \mathrm{m})$ that is encircled by folds. The two sensillar types are often found intermingled with each other.

The peg of the sensilla trichodea A (Fig. 5) is smooth and has a slightly tuberculoid base that is connected to the surrounding cuticle via a jointlike membrane. The s. trichodea $\mathrm{A}$ are found mainly on the dorsal side of male and female antennae. They also occur in fewer numbers laterally at the inside of the annuli, but are much shorter there (about $5 \mu \mathrm{m}$ compared to 8.6-9.7 $\mu \mathrm{m}$ dorsally). In males the annuli $3-11$, in females the annuli 2-10 are equipped with these sensilla, with the highest density at the apex of the antenna in both sexes.

The sensilla trichodea B (Fig. 6) have longitudinal furrows and a narrow socket. In most cases they are bent slightly downwards (towards the antennal surface). In the crater surrounding the sensillum two little holes can be seen (Fig. 6). These very thin and sharp-tipped sensilla are found on the annuli $1-10$ on the ventral and on the annuli $2-10$ on the dorsal side of female antennae. In males they occur on the annuli 2-11 dorsally and 3-11 ventrally. The most distal annuli bear more sensilla of this type than the proximal ones. Lengths measured were usually in the range of $8.8-9.3 \mu \mathrm{m}$ at a width of only $0.9 \mu \mathrm{m}$.

The antennae of beewolf males and females bear a group of sensilla (Fig. 7). of variable size that very closely resemble the s. trichodea C/D described by Ågren (1989) for other sphecid wasps (see also Esslen \& Kaissling 1976). Esslen \& Kaissling (1976) differentiated the s. trichodea C

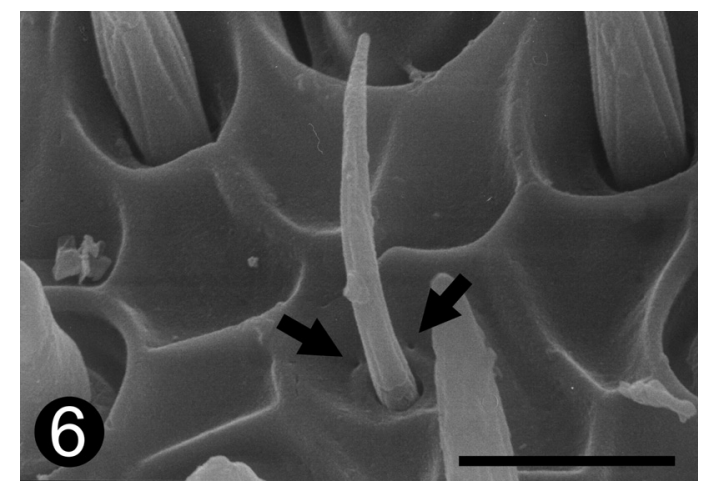

Fig. 6. Female, 9th annulus, dorsal side. Sensillum trichodeum B. Arrows point to little holes at the base of the sensillum. Scale bar $5 \mu \mathrm{m}$.

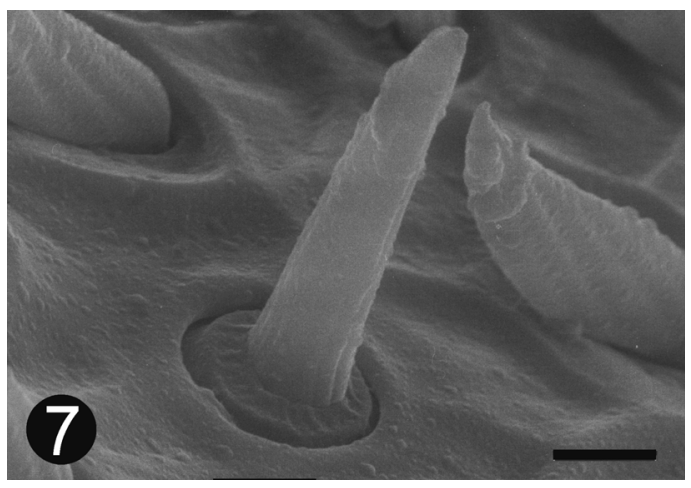

Fig. 7. Male, 10th annulus, dorsal side. Sensillum trichodeum C/D. Scale bar $2 \mu \mathrm{m}$.

and D in honeybees by, among other things, the sharpness of the tip. These two types are not differentiated here, since they were not separable by SEM, due to their uniformly rather blunt tips in $P$. triangulum. S. trichodea $\mathrm{C} / \mathrm{D}$ are characterized by longitudinal furrows and a wide, possibly flexible socket. There are indications of an apical pore. They occur in both sexes, in females on all annuli dorsally and ventrally, in males on all annuli dorsally and on the ventral side from annuli 2-11. In females very few s. trichodea C/D can also be found on the scape and pedicel. The sensillum length is very variable and ranges from 8 to almost $16 \mu \mathrm{m}$, at a relatively constant width of 1.8-2.2 $\mu \mathrm{m}$. While the shorter sensilla are mainly found close to the ventral or dorsal midline, there is a row of very long sensilla laterally. 


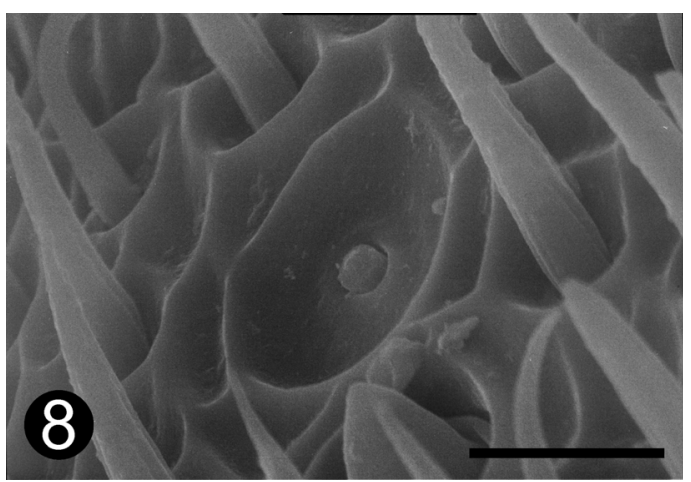

Fig. 8. Male, 11th annulus, dorsal side. Sensillum coelocapitulum. Scale bar $5 \mu \mathrm{m}$.

S. trichodea C/D are sometimes slightly curved upwards from the antennal surface.

The outer morphology of the sensillum coelocapitulum (Fig. 8) is very distinct with an oval concavity (8-8.6 $\mu \mathrm{m}$ across) having a central opening and a button-like protrusion with an irregular surface (1.3-1.4 $\mu \mathrm{m}$ in diameter) from the opening. This sensillum type occurs on the ventral side of male and female antennae, as well as on the very tip of the flagellar apex. It is scattered over the antenna in small numbers and it is usually found in the vicinity of pit organs. The s. coelocapitula occur on most annuli in males and females.

We found one sensillar type that can be assigned to the so-called grooved peg sensilla (Fig. 9; Hawke \& Farley 1971, McIver 1974, Altner \& Prillinger 1980, Zacharuk 1980, Keil 1999). It can be found in small numbers in males and females, but only on the dorsal side and only from annulus 6-11 in males and 6-10 in females. The peg rises about $8.5-9.5 \mu \mathrm{m}$ above the surface and is $2.36-2.5 \mu \mathrm{m}$ wide. The base of the peg is sunken below the surrounding cuticular surface and not clearly visible. Deep longitudinal furrows (or grooves) are characteristic for this sensillar type.

Setae are present on all annuli plus the scape and pedicel in males and females. They are found all around the annuli, but are most numerous on the ventral surfaces. They do not appear in one particular shape, but form a divers class of hairs. Most setae have deep longitudinal or spiral furrows, some are rather thick, especially on the distal

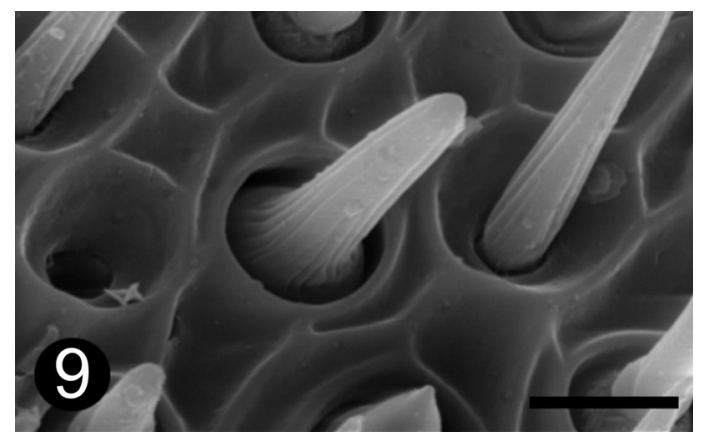

Fig. 9. Female, 7th annulus, dorsal side. Grooved peg sensillum. Scale bar $5 \mu \mathrm{m}$.

annuli. One form is smooth and sabre-shaped and connected to the cuticle almost over its whole length.

The setae on the first annulus are thin and longer than the ones on all other annuli. The longest setae (up to four times longer than the ones found on the annuli), however, are located on the scape. The setae at the apex of the antennae are often hooked. The tips of the setae are always tapered sharply, the sockets not prominent.

\section{Discussion}

\subsection{General morphology}

The antennal form of $P$. triangulum is similar to that in many Apidae (Esslen \& Kaissling 1976, Ågren 1977, 1978, 1989, Ågren \& Svensson 1982). However, whereas honeybees bend their flagella downwards in flight, beewolves fly with their antennae held straight. Furthermore, in beewolves the flagellum is thickened possibly due to the presence of complex glands in females that have a function in communication between the mother and her progeny (Strohm \& Linsenmair 1994/95).

An area almost free of sensilla on the ventral side of the most distal annulus has also been reported for Cerceris rybyensis (Ågren 1989) that belongs to the subfamily beewolves (Philanthinae), in many species of Sphecodes bees (Ågren \& Svensson 1982), some Halictidae (Wcislo 1995) and Apis mellifera (Esslen and Kaissling 1976). The function of this conspicuously unarmed area is not known. 


\subsection{Sensilla types}

The most conspicuous sensillar characteristic in the European beewolf is the bulbous form of the $\mathrm{s}$. placodea and the stout appearance of the large s. basiconica, which seem to be typical for the family Sphecidae (Martini 1986a, b, Ågren 1989). The short peg-like s. placodea of $P$. triangulum closely resemble those of two other philanthine species Cerceris quinquefasciata (Martini 1986b) and $C$. rybyensis (Ågren 1989) and are still very similar to other sphecids like Bembix rostrata, Psenulus concolor, Argogorytes fargei, and A. mystaceus (Martini 1986b, Ågren 1989). In Apis mellifera (Esslen \& Kaissling 1976) and many Bombus species (Ågren \& Hallberg 1996) as well as in some species of Halictidae, Andrenidae, and Colletidae (Ågren 1977, 1978, Ågren \& Svensson 1982) the s. placodea do not rise above the antennal surface. Martini (1986b) designated the s. placodea of other sphecid species, e.g. C. quinquefasciata, to the group of multiporous, single-walled sensilla with an olfactory function. In Apis mellifera s. placodea are known to be olfactory receptors (Lacher 1964, Esslen \& Kaissling 1976).

The closest similarity of the stout, cylindrical s. basiconica of the European beewolf, with their wide membranous sockets, can again be found in other sphecids, like C. rybyensis (Ågren 1989) or P. concolor (Martini 1986a). In the Apidae the s. basiconica are typically rather slender and long pegs with small sockets, a form that is considered more derived than the one found in the Sphecidae (Walther 1983, Ågren 1989). In P. triangulum only females possess the large s. basiconica. This is also the case in the sphecid wasps Psenulus concolor and Dolichurus corniculus (Martini 1986a) as well as in Argogorytes fargei and A. mystaceus (Ågren 1989). In contrast, males of Cerceris rybyensis and Bembix rostrata ( $\mathrm{Agren}$ 1989) as well as Sceliphron spirifex, Trypoxylon attenuatum, Ectemnius cavifromis (Martini 1986a) do possess s. basiconica. In A. mellifera, male antennae do not bear this sensillum (Esslen and Kaissling 1976). Considering the sensillar pore equipment and observations made in different species, the large s. basiconica may function as olfactory or gustatory sensilla (Slifer \& Sekhon 1961, Martini 1986a, Ågren 1989, Gnatzy et al. 1990). The fact that in the European beewolf s. basiconica are only found in females suggests that they are involved in the location and identification of their only prey, honeybee workers. In the digger wasp Liris niger the sensilla basiconica have been reported to be essential for prey recognition (Gnatzy et al. 1990).

The morphologies of the s. trichodea A, B, C/ D, the s. coelocapitula, s. ampullacea, s. coeloconica do not deviate considerably from those observed in A. mellifera (Esslen \& Kaissling 1976, Yokohari et al. 1982). The base of the s. trichodea A is more tuberculoid in $P$. triangulum than in honeybee workers. S. trichodea A have a similar appearance in B. rostrata and C. rybyensis (Ågren 1989). In other species these sensilla have been described as single-walled hairs with wall pores, which suggests an olfactory function (Slifer \& Sekhon 1961, Ågren \& Hallberg 1996).

The thin s. trichodea B are found either straight or bent towards the antennal surface. Since no other morphological difference can be found, we do not differentiate between the s. trichodeum B1 and B2 like Esslen \& Kaissling (1976) did in A. mellifera. This variation in curvature of the s. trichodea B has also been reported in Halictidae (Wcislo 1995). The function of the two little holes situated in the socket of each s. trichodeum B in $P$. triangulum is not clear. The holes could be pores or release sites of antennal glands as described by Isidoro et al. (1996). Bin et al. (1989) describes a close association of glands with sensilla in the parasitoid wasp Trissolcus basalis (see also Bartlet et al. 1994). According to Lacher (1964) and McIver (1975) the s. trichodea B have a mechanosensitive function.

The two types of s. trichodea, C and D, as identified in A. mellifera by Esslen \& Kaissling (1976), were not distinguishable by SEM. The sizes of the s. trichodea C/D vary considerably. A similar variation in sensillum size has also been recorded in Apis (Esslen \& Kaissling 1976), some Bombus species (Ågren \& Hallberg 1996), Bembix rostrata (Ågren 1989), and Sphecodes bees (Ågren $\&$ Svensson 1982). From structural characteristics and electrophysiological investigations a combined mechanosensory-gustatory function has been inferred (Lacher 1964, Esslen \& Kaissling 1976, Ågren \& Hallberg 1996).

The pit organs s. ampullacea and s. coeloconica could not be distinguished by characters 
at the surface of the antenna alone. The cuticular openings of the two pit organs do not differ much in diameter, and there is too much variation to assign a sensillum to one or another pit organ type unambiguously. The same problem has been described for the leaf-cutter ant Atta sexdens (Kleineidam 1999, Kleineidam et al. 2000) and two Andrena species (Ågren 1978). In A. mellifera (Dietz \& Humphreys 1971), some Bombus species (Ågren \& Hallberg 1996), as well as the ants Cataglyphis bicolor and C. bombycinus (Riedl 1995), the diameter of the external opening of the s. ampullacea is much smaller than that of the s. coeloconica, which allows a clear differentiation of the two types by their outer appearance.

Not all insect species possess two types of pit organs (Ågren 1989). The semi-thin sections of antennae of the European beewolf revealed that the anatomy of the s. ampullacea and s. coeloconica is similar to these sensilla in the ants Formica rufa (Walther 1981), Atta sexdens (Kleineidam 1999), Cataglyphis bicolor and $C$. bombycinus (Riedl 1995). In other insect species the peg of the s. coeloconica protrudes over the antennal surface or is at least clearly visible from the outside (e.g. in the bees Augochlora pura [Wcislo 1995] and Andrena vaga [Ågren 1978], and in the red wood ant Formica rufa [Walther 1981]). Kleineidam $(1999,2000)$ identified the $s$. ampullacea as $\mathrm{CO}_{2}$-receptors in Atta sexdens by electrophysiological methods. A thermo-, hygroand $\mathrm{CO}_{2}$ - receptive function has been proposed for s. ampullacea in Coleoptera (Guse \& Honomichl 1980) and Diptera (McIver 1982). An olfactory function has been assigned to the coeloconic sensilla in Locusta migratoria (Boeckh 1967, Altner \& Prillinger 1980, Altner et al. 1981).

The sensilla coelocapitula do occur on the antennae of several other hymenopteran species like the honeybee Apis mellifera (Dietz \& Humphreys 1971, Esslen \& Kaissling 1976, Yokohari et al. 1982, Yokohari 1983), bumblebees (Ågren \& Hallberg 1996), Andrena tibialis and A. vaga (Ågren 1978), Bembix rostrata (Ågren 1989), Cerceris rybyensis (Ågren 1989), eleven species of Sphecodes bees (Ågren 1982), and two ant species Cataglyphis bicolor and $C$. bombycinus (Riedl 1995). They were not found in Argogorytes fargei (Ågren 1989) or in eleven taxa of Halictidae (Wcislo 1995).
In most of these cited works, the mentioned sensillar type has been referred to as sensillum campaniformium (Dietz \& Humphreys 1971, Esslen \& Kaissling 1976, Ågren 1978, Ågren 1989, Riedl 1995). Yokohari et al. (1982), however, reidentified this type of sensillum as a coelocapitular sensillum, because it does not resemble the true campaniform sensillum described by Moran et al. (1971), which has a dome-shaped (convex) central protrusion. The coelocapitular sensilla on the antennae of $P$. triangulum are relatively large compared to the ones in Apis mellifera (Yokohari et al. 1982). The association of s. coelocapitula with pit organs (s. coeloconica and/ or s. ampullacea) has also been reported in the honeybee (Dietz \& Humphreys 1971, Yokohari et al. 1982), Bembix rostrata (Ågren 1989), Andrena tibialis and A. vaga (Ågren 1978), and some Sphecodes bees (Ågren 1982). The sensilla coelocapitula are hygro-and thermoreceptors in Apis mellifera (Yokohari et al. 1982, Yokohari 1983) (whereas the campaniform sensilla have been shown to function as proprioceptive mechanoreceptors [Iwasaki et al. 1999]).

The grooved peg sensilla are very variable in their appearance. They range from small, peg-like structures (Lewis 1971, McIver 1974) to large hairs (Lambin 1973, Hawke \& Farley 1971). In $P$. triangulum they are relatively long and thick. These sensilla either stand on a small socket (Hallberg 1979), arise directly from the antennal surface (McIver 1974) or are sunken slightly below the surrounding cuticular surface with their base, as described here for $P$. triangulum. The characteristic morphological feature visible in SEM studies are the deep longitudinal grooves ranging from near the base (as in $P$. triangulum) or about the middle of the peg to the tip. The grooved pegs seem to be common in Diptera like e.g. the fly Stomoxys calcitrans (Lewis 1971), the mosquito Aedes aegypti (McIver 1974, Cribb \& Jones 1995), the malaria mosquito Anopheles gambiae (Meijerink et al. 2001), and several syrphid flies (Henderson \& Wellington 1982). It also occurs in the cockroach species Periplaneta americana (Altner et al. 1977), Blaberus craniifer (Lambin 1973), and Arenivaga sp. (Hawke \& Farley 1971). The migratory locust Locusta migratoria (Steinbrecht 1969), the blood sucking bug Triatoma infestans (Guerenstein \& Guerin 
2001), the mealworm beetle Tenebrio molitor (Harbach \& Larsen 1977), as well as many other species of Coleoptera and Homoptera also possess grooved pegs. Despite the wide distribution of this sensillar type in many different taxa, to our knowledge, it has not been described in the Hymenoptera so far. The grooved peg sensilla are presumably double-walled wall-pore sensilla (DW-WP in Altner [1977]) with an olfactory function (e.g. Zacharuk 1980, Steinbrecht 1996, Keil 1999, Guerenstein \& Guerin 2001). Sometimes the s. coeloconica are also denominated grooved pegs, since they belong to the DW-WP sensilla and function as olfactory receptors (Altner \& Prillinger 1980). Keil (1999) made a distinction between DW-WP sensilla sunken in pits $(=\mathrm{s}$. coeloconica) and those with a hairlike structure above the cuticular surface (= grooved pegs).

The different types of sensilla could not always be unequivocally distinguished by SEM. There seem to be transitional forms between some types of sensilla. It is also not clear whether all the different types of setae are uninnervated hairs. TEM and electrophysiological investigations will reveal more morphological details and the function of the different types of sensilla.

In conclusion, beewolves possess a large number of different sensilla and a high density. Five of the nine sensillar types possibly have an olfactory function. With regard to our initial question about differences between the sexes in the equipment with sensilla there was a qualitative difference in that males lack the large s. basiconica. This suggests that the s. basiconica have a function in location or identification of the prey of the females, honeybee workers.

It has also to be taken into account that the functional diversity of sensilla is much greater than the number of morphological types (Zacharuk 1980, Steinbrecht 1996). Morphologically similar sensilla may have different numbers of sensory cells, different specificities and different response characteristics, not only in different insect species, but also between the sexes of the same species (Davies 1977, Städler 1978). Hence, differences in olfactory abilities of males and females might be more pronounced than suggested by differences in morphology of the sensilla. Also, most recent results show a sexual dimorphism in the antennal lobes of beewolves, involving the num- bers of glomeruli as well as the size of identified homologous glomeruli in the brains of males and females (J. Rybak pers. comm.).

Acknowledgements. We are grateful to the Central Division of Electron Microscopy, Würzburg University, for technical support. We wish to thank Andrea Hilpert for help with the semithin sections of the antennae and Lennart Ågren and Christoph Kleineidam for helpful discussion. This study was supported by the DFG (SFB 554 TP B3).

\section{References}

Ågren, L. 1977: Flagellar sensilla of some Colletidae (Hymenoptera: Apoidea). - Int. J. Insect Morphol. Embryol. 6: 137-146.

Ågren, L. 1978: Flagellar sensilla of two species of Andrena (Hymenoptera: Andrenidae). — Int. J. Insect Morphol. Embryol. 7: 73-79.

Ågren, L. 1989: Flagellar sensillum patterns in Nyssoninae and Philanthinae wasps (Hymenoptera, Sphecidae). Zool. Scr. 18: 527-535.

Ågren, L. \& Hallberg, E. 1996: Flagellar sensilla of bumble bee males (Hymenoptera, Apidae, Bombus). Apidologie 27: 433-444.

Ågren, L. \& Svensson, B. G. 1982: Flagellar Sensilla of Sphecodes Bees (Hymenoptera, Halictidae). — Zool. Scr. 11: 45-54.

Altner, H. 1977: Insect sensillum specifity and structures: an approach to a new typology. - In: Le Magnen, L. \& MacLeod, P. (eds.), Olfaction and taste VI: 295303. Information Retrieval, London.

Altner, H., Sass, H. \& Altner, I. 1977: Relationship between structure and function of antennal chemo-, hygro-, and thermoreceptive sensilla in Periplaneta americana. Cell Tissue Res. 176: 389-405.

Altner, H. \& Prillinger, L. 1980: Ultrastructure of Invertebrate Chemo-, Thermo-, and Hygroreceptors and its Functional Significance. — Int. Rev. Cytol. 67: 69139.

Altner, H., Routil, C. \& Loftus, R. 1981: The structure of bimodal chemo-, thermo-, and hygroreceptive sensilla on the antenna of Locusta migratoria. - Cell Tissue Res. 215: 289-308.

Attygalle, A. B., Jham, G. N., Svatos, A., Frighetto, R. T., Ferrara, F. A., Vilela, E. F., Uchoa-Fernandes, M. A. \& Meinwald, J. 1996: (3E,8Z,11Z)-3,8,11-tetradecatrienyl acetate, major sex pheromone component of the tomato pest Scrobipalpuloides absoluta (Lepidoptera: Gelechiidae). - Bioorg. Med. Chem. 4: 305-314.

Bartlet, E., Isidoro, N. \& Williams, I. H. 1994: Antennal glands in Psylliodes chrysocephala, and their possible role in reproductive behaviour. - Physiol. Entomol. 19: $241-250$.

Bin, F., Colazza, S., Isidoro, N., Solinas, M. \& Vinson, S. B. 1989: Antennal chemosensilla and glands, and their 
possible meaning in the reproductive behaviour of Trissolcus basalis (Woll.) (Hym.: Scelionidae). Entomologica 24: 33-97.

Boeckh, J. 1967: Reaktionsschwelle, Arbeitsbereich und Spezifität eines Geruchsrezeptors auf der Heuschreckenantenne. — Z. Vgl. Physiol. 155: 378406.

Cossé, A. A., Todd, J. L., Millar, J. G., Martínez, L. A., \& Baker, T. C. 1995: Electroantennographic and coupled gas chromatographic-electroantennographic responses of the mediterranean fruit fly, Ceratitis capitata, to maleproduced volatiles and mango odor. - J. Chem. Ecol. 21: 1823-1836.

Cribb, B. W. \& Jones, M. K. 1995: Reappraisal of the pore channel system in the grooved pegs of Aedes aegypti. - Tissue Cell 27: 47-53.

Davies, E. E. 1977: Response of the antennal receptors of the male Aedes aegypti mosquito. - J. Insect Physiol. 23: 613-617.

Dietz, A. \& Humphreys, W. 1971: Scanning electron microscopic studies of antennal receptors of the worker honey bee including sensilla campaniformia. - Ann. Entomol. Soc. Am. 64: 919-925.

Drijfhout, F. P. \& Groot, A. T. 2001: Close-range attraction in Lygocoris pabulinus (L.). - J. Chem. Ecol. 27: 11331149.

Esslen, J. \&. Kaissling, K.-E. 1976: Zahl und Verteilung antennaler Sensillen bei der Honigbiene (Apis mellifera L.). — Zoomorphologie 83: 227-251.

Evans, H. E. \& O’Neill, K. M. 1988: The natural history of North American beewolves. - Cornell University Press, Ithaca.

Gnatzy, W., Anton, S. \& Thier, S. 1990: Prey specifity and prey recognition in the digger wasp Liris niger Fabr.: The Importance of close range chemical cues. - In: Gribakin, F. G., Wiese, K. \& Popov, A. V. (eds.), Sensory Systems and Communication in Arthropods: 2125. Birkhäuser Verlag, Basel.

Guerenstein, P. G. \& Guerin, P. M. 2001: Olfactory and behavioral responses of the blood-sucking bug Triatoma infestans to odours of vertebrate hosts. - J. Exp. Biol. 204: 585-597.

Guse, G. W. \& Honomichl, K. 1980: Die digitiformen Sensillen auf dem Maxillarpalpus von Coleoptera. II Feinstruktur bei Agabus bipustulatus (L) und Hydrobius fuscipes (L). — Protoplasma 103: 55-68.

Hallberg, E. 1979: The fine structure of the antennal sensilla of the pine saw fly Neodiprion sertifer (Insecta: Hymenoptera). - Protoplasma 101: 111-126.

Hansson, B. S. 1995: Olfaction in Lepidoptera. Experientia Basel 51: 1003-1027.

Harbach, R. E. \& Larsen, J. R. 1977: Fine structure of antennal sensilla of the adult mealworm beetle Tenebrio molitor (Coleoptera, Tenebrionidae). - J. Insect Morphol. Embryol. 6: 41-60.

Hawke, S. D. \& Farley, R. D. 1971: Antennal chemoreceptors of the desert burrowing cockroach, Arenivaga sp. - Tissue Cell 3: 649-664.
Henderson, D. E. H. \& Wellington, W. G. 1982: Antennal sensilla of some aphidophagous Syrphidae, Diptera. Fine Structure and Electroantennogram study. — Can. J. Zool. 60: 3172-3186.

Inouchi, J., Shibuya, T., Matsuzaki, O. \& Hatanaka, T. 1987: Distribution and fine structure of antennal olfactory sensilla in Japanese dung beetles, Geotrupes auratus Mtos. (Coleoptera: Geotrupidae) and Copris pecuarius Lew. (Coleoptera: Scarabaeidae). — Int. J. Insect Morphol. Embryol. 16: 177-187.

Isidoro, N., Bin, F., Colazza, S. \& Vinson, S. B. 1996: Morphology of Antennal Gustatory Sensilla and Glands in Some Parasitoid Hymenoptera With Hypothesis on Their Role in Sex and Host Recognition. - J. Hym. Res. 5: 206-239.

Iwasaki, M., Itoh, T. \& Tominaga, Y. 1999: Mechano- and Phonoreceptors. - In: Eguchi, E. \& Tominaga, Y. (eds.), Atlas of Arthropod Sensory Receptors: 177-190. Springer-Verlag, Tokyo.

Jourdan, H., Barbier, R., Bernard, J. \& Ferran, A. 1995: Antennal sensilla and sexual dimorphism of the adult ladybird beetle Semiadalia undecimnotata Schn. (Coleoptera: Coccinellidae). — Int. J. Insect Morphol. Embryol. 24: 307-322.

Keil, T. A. 1998: The Structure of Integumental Mechanoreceptors. - In: Harrison, F. W. \& Locke, M. (eds.), Microscopic Anatomy of Invertebrates: 385 404. Wiley-Liss, New York.

Keil, T. A. 1999: Morphology and development of the peripheral olfactory organs. - In: Hansson, B. S. (ed.), Insect Olfaction: 5-47. Springer-Verlag.

Kim, J.-Y. \& Leal, W. S. 2000: Ultrastructure of pheromonedetecting sensillum placodeum of the Japanese beetle, Popillia japonica Newman (Coleoptera: Scarabaeidae). - Arth. Struc. Devel. 29: 121-128.

Kleineidam, C. 1999: Sensory Ecology of Carbon Dioxide Perception in Leaf-cutting Ants. - Bayerische JuliusMaximilians-Universität, Würzburg.

Kleineidam, C., Romani, R., Tautz, J. \& Isidoro, N. 2000: Ultrastructure and physiology of the $\mathrm{CO}_{2}$ sensitive sensillum ampullaceum in the leaf-cutting ant Atta sexdens. - Arth. Struc. Devel. 29: 43-55.

Lacher, V. 1964: Elektrophysiologische Untersuchungen an einzelnen Rezeptoren für Geruch, Kohlendioxid, Luftfeuchtigkeit und Temperatur auf den Antennen der Arbeitsbiene und der Drohne (Apis mellifica L.). - Z Z . Vgl. Physiol.48: 587-623.

Lambin, M. 1973: Les sensilles de l'antenne chez quelques blattes et en particulier chez Blaberus craniifer (Burm.). —Z. Zellforsch. Mikrosk. Anat. 143: 183-206.

Lewis, C. T. 1971: Superficial sense organs of the antennae of the fly, Stomoxys calcitrans. - J. Insect Physiol. 17: 449-461.

Martini, R. 1986a: Fine Structure and Development of the Large Sensilla Basiconica on the Antennae of Sphecid Wasps. - Tissue Cell Res. 18: 143-151.

Martini, R. 1986b: Ultrastructure and development of single-walled sensilla placodea and basiconica on the an- 
tennae of the sphecoidea (Hymenoptera: Aculeata). Int. J. Insect Morphol. Embryol. 15: 183-200.

McIver, S. B. 1974: Fine structure of antennal grooved pegs of the mosquito, Aedes aegypti. - Cell Tissue Res. 153: 327-337.

McIver, S. B. 1975: Structure of cuticular mechanoreceptors of Arthropods. - Annu. Rev. Entomol. 20: 381-397.

McIver, S. B. 1982: Sensilla of Mosquitoes (Diptera: Culicidae). — J. Med. Entomol. 19: 489-535.

Meijerink, J., Braks, M. A. H. \& Van Loon, J. J. A. 2001: Olfactory receptors on the antennae of the malaria mosquito Anopheles gambiae are sensitive to ammonia and other sweat-borne components. - J. Insect Physiol. 47: 455-464.

Merivee, E., Rahi, M. \& Luik, A. 1999: Antennal sensilla of the click beetle, Melanotus villosus (Geoffroy) (Coleoptera: Elateridae). — Int. J. Insect Morphol. Embryol. 28: 41-51.

Moran, D. T., Chapman, K. M. \& Ellis, R. A. 1971: The fine structure of cockroach campaniform sensilla. - J. Cell. Biol. 48: 155-173.

Nishida, R., Schulz, S., Kim, C. S., Fukami, H., Kuwahara, Y., Honda, K. \& Hayashi, N. 1996: Male Sex Pheromone of a Giant Danaine Butterfly, Idea leuconoe. — J. Chem. Ecol. 22: 949-972.

Olberg, G. 1953: Der Bienenfeind Philanthus. — Akademische Verlagsgesellschaft Geest \& Portig K.-G., Leipzig.

Paulmier, I., Bagneres, A.-G., Afonso, C. M. M., Dusticier, G., Riviere, G. \& Clement, J.-L. 1999: Alkenes as a sexual pheromone in the alfalfa leaf-cutter bee Megachile rotundata. - J. Chem. Ecol. 25: 471-490.

Phelan, P. L. 1992: Evolution of sex pheromones and the role of asymmetric tracking. - In: Roitberg, B. \& Isman, M. (eds.), Insect Chemical Ecology: 265-314. Chapman and Hall, New York.

Phelan, P. L. 1997: Evolution of mate-signaling in moth: phylogenetic considerations and predictions from a asymmetric tracking hypothesis. - In: Choe, J. \& Crespi, B. (eds.), The evolution of mating systems in insects and arachnids: 240-256. Cambridge University Press, Cambridge.

Rathmayer, W. 1962: Das Paralysierungsproblem beim Bienenwolf Philanthus triangulum F. (Hym. Sphec.). -Z. vergl. Physiol. 45: 413-462.

Riedl, P. 1995: Morphologie und Verteilung der Cuticularsensillen auf den Antenngeisseln von Cataglyphis bicolor and C. bombycinus (Formicidae, Hymenoptera). —Zoologisches Institut der Universität Zürich. Universität Zürich, Zürich.

Romeis, B. 1989: Mikroskopische Technik. — Urban und Schwarzenberg, München, Wien, Baltimore.

Schenk, O. 1903: Die antennalen Hautsinnesorgane einiger Lepidopteren und Hymenopteren mit besonderer Berücksichtigung der sexuellen Unterschiede. Zool. Jahrb. — Abt. Anat. Ontog. Tiere 17: 573-618.

Slifer, E. \& Sekhon, S. S. 1961: Fine structure of the sense organs on the antennal flagellum of the honey-bee, Apis mellifera L. - J. Morph. 109: 351-381.
Städler, E. 1978: Chemoreception of host plant chemicals by ovipositing females of Delia (Hylemya) brassicae. — Entomol. Exp. Appl. 24: 511-520

Steinbrecht, R. A. 1969: Comparative morphology of olfactory receptors. - In: Pfaffmann, C. (ed.), Olfaction and Taste, vol III: 3-21. Rockefeller University Press, New York.

Steinbrecht, R. A. 1996: Structure and function of insect olfactory sensilla. - In: Olfaction in mosquito-host interactions: 159-177. Ciba Foundation Symposium 200, John Wiley \& Sons.

Strohm, E., Laurien-Kehnen, C. \& Bordon, S. 2001: Escape from parasitism: Spatial and temporal strategies of a sphecid wasp against a specialised cuckoo wasp. — Oecologia 129: 50-57.

Strohm, E. \& Lechner, K. 2000: Male size does not affect territorial behaviour and the life history traits in a sphecid wasp. - Anim. Behav. 59: 183-191.

Strohm, E. \& Linsenmair, K. E. 1994/1995: Leaving the cradle: how beewolves (Philanthus triangulum F.) obtain the necessary spatial information for emergence. —Zoology 98: 137-146.

Tinbergen, N. 1932: Über die Orientierung des Bienenwolfes (Philanthus triangulum Fabr.). - Z . Vgl. Physiol. 16: 305-335.

Tinbergen, N. 1935: Über die Orientierung des Bienenwolfes. II. Die Bienenjagd. —Z. Vgl. Physiol. 21:699-716.

Tinbergen, N. \& Kruyt, W. 1938: Über die Orientierung des Bienenwolfes. III. Die Bevorzugung bestimmter Wegmarken. - Z. Vgl. Physiol. 25: 292-334.

van Baaren, J., Boivin, G., Le Lannic, J. \& Nenon, J.-P. 1999: Comparison of antennal sensilla of Anaphes victus and A. listronoti (Hymenoptera, Mymaridae), egg parasitoids of Curculionidae. - Zoomorphology 119: 1-8.

Walther, J. R. 1981: Die Morphologie und Feinstruktur der Sinnesorgane auf den Antenngeisseln der Männchen, Weibchen und Arbeiterinnen der Roten Waldameise Formica rufa Linne 1758 mit einem Vergleich der antennalen Sensillenmuster weiterer Formicoidea (Hymenoptera). Fachbereich Biologie. Freie Universität, Berlin.

Walther, J. R. 1983: Antennal patterns of sensilla of the Hymenoptera - a complex character of phylogenetic reconstruction. - Verh. Naturw. Ver. Hamb. (NF) 26: 373-392.

Wcislo, W. T. 1995: Sensilla numbers and antennal morphology of parasitic and non-parasitic bees (Hymenoptera: Apoidea). - Int. J. Insect Morphol. Embryol. 24: 63-81.

Yarden, G., Shani, A. \& Leal, W. S. 1996: (Z,E)-[alpha]Farnesene - An Electroantennogram-Active Component of Maladera matrida Volatiles. - Bioorg. Med. Chem. 4: 283-287.

Yokohari, F. 1983: The coelocapitular sensillum, an antennal hygro- and thermoreceptive sensillum of the honey bee, Apis mellifera L. - Cell Tissue Res. 233: 355-365.

Yokohari, F., Tominaga, Y. \& Tateda, H. 1982: Antennal hygroreceptors of the honey bee, Apis mellifera L. Cell Tissue Res. 226: 63-73.

Zacharuk, R. Y. 1980: Ultrastructure and Function of Insect Chemosensilla. - Annu. Rev. Entomol. 25: 27-47. 